\title{
As Representações Maternas acerca do Bebê que Nasce com Doenças Orgânicas Graves ${ }^{1}$
}

\author{
Ethel Cukierkorn Battikha² \\ Universidade Federal de São Paulo \\ Maria Cecília Correa de Faria \\ Pontifícia Universidade Católica de São Paulo \\ Benjamin Israel Kopelman \\ Universidade Federal de São Paulo
}

\begin{abstract}
RESUMO - O nascimento de um bebê com doenças orgânicas graves tem profundas implicações na constituição do vínculo inicial mãe-bebê. $O$ objetivo desta pesquisa é a investigação das representações psíquicas maternas acerca desse nascimento. Este estudo qualitativo está fundamentado no campo teórico-psicanalítico. Foram realizadas entrevistas semi-estruturadas, individuais, com 11 mães no período de internação do bebê na Unidade de Terapia Intensiva Neonatal. Os dados obtidos foram submetidos ao método de análise de conteúdo e revelaram que o nascimento do bebê com alterações orgânicas afeta a função materna já que desorganiza as representações que eram antes dirigidas ao bebê sadio imaginado, marcando uma tendência recorrente à equivalência desse bebê ao diagnóstico de sua doença. Este nascimento implica, portanto, o luto pelo filho desejado e o decréscimo da auto-estima materna. A participação nas entrevistas teve efeitos terapêuticos, sugerindo a necessidade de uma escuta analítica dessas mães durante o período de permanência do bebê na instituição hospitalar.
\end{abstract}

Palavras-chave: Psicanálise; terapia intensiva neonatal; relações mãe-filho; bebês com problemas.

\section{The Maternal Representations about a Baby who is Born with Serious Organic Diseases}

\begin{abstract}
The birth of a baby with serious organic diseases has deep implications in the constitution of the initial link mother-baby. This research aims at investigating the maternal psychic representations about this birth. This qualitative study is based on the psychoanalytic-theoretical field. Semi- structured individual interviews with 11 mothers were carried out during the period of the baby hospitalization in the neonatal ICU. The obtained data were submitted to the content analysis method and showed that the birth of the baby with organic disturbances affects the maternal role, as it disorganizes the representations that were directed before to the idealized healthy baby, marking a recurrent tendency to the equivalence of this baby with his/her disease diagnosis. This birth implies, therefore, in the mourning of the desired child and in the decrease of the maternal self-esteem. The participation in the interviews had therapeutical effects, suggesting the need of an analytycal listening of these mothers during the period the baby remains in the hospital.
\end{abstract}

Key words: Psychoanalysis; intensive neonatal therapy; mother-child relations; babies with problems.

O bebê nasce absolutamente dependente. A mãe identificada com esse bebê é capaz de colocar-se no seu lugar e adaptar-se às suas necessidades (Winnicott, 1956/1993). Em nome da ilusão de completude na relação com seu filho é capaz de suspender seus outros interesses no mundo a favor de seu bebê, que está colocado, portanto, na comple- mentação narcísica ${ }^{3}$ da mãe (Baranger, 1994; Bleichmar, 1983; Freud, 1914).

Freud (1914), no artigo Sobre o Narcisismo: uma introdução, refere-se à atitude afetuosa dos pais como revivescência e reprodução do próprio narcisismo; ao filho são atribuídas as perfeições e ocultadas ou esquecidas as deficiências:

(...) sentem-se inclinados a suspender em favor da criança o funcionamento de todas as aquisições culturais que seu próprio

3 O enfoque neste artigo remete ao narcisismo, entendido segundo Bleichmar (1983), como a valorização que o sujeito faz de si mesmo, como a significação que o ego como representação de si toma para o sujeito quer dizer, como é que se situa numa escala de preferências, de valores. A denominação ferida narcísica refere-se a tudo que venha a diminuir a auto-estima da pessoa ou seu sentimento de ser amada por "objetos" valorizados. 
narcisismo foi forçado a respeitar e a renovar em nome delas as reivindicações aos privilégios de há muito por eles próprios abandonados (...) ela será mais uma vez realmente o centro e o âmago da criação. Sua majestade, o bebê (p.108).

O nascimento de um bebê porta o futuro da linhagem parental. Reconhecer-se no filho sustenta a fantasia dos pais de continuidade e de imortalidade e isso faz o nascimento ser celebrado. Quando alguém olha um bebê e comenta sobre sua beleza, ou quando se refere a qualquer outro atributo positivamente valorizado, a mãe comumente agradece. Esse elogio é tomado como a confirmação de sua potência-competência. Seu olhar é de admiração, o bebê é seu cetro e ela, sua majestade, a mãe deste bebê.

Em torno do bebê que acaba de nascer tece-se, consciente e inconscientemente, uma rede de expectativas e desejos: as marcas fundantes da subjetividade dessa criança, sustentadas nesse vínculo inicial mãe-bebê.

Todo nascimento mobiliza um certo grau de angústia nos pais e um remanejamento psíquico profundo; quando se trata de um nascimento prematuro é uma "tempestade psíquica" que se abate sobre o casal (Druon, 1999). E quando o bebê nasce com, ou muito precocemente apresenta alterações orgânicas graves que deixam seqüelas? No nascimento ordinário referimos à sua majestade, o bebê (Freud, 1914). No nascimento prematuro, a aposta é sustentada: Será ele um rei? E no nascimento de uma criança com alterações orgânicas graves? Qual a fantasia materna diante dele? (Mathelin, 1999; Wanderley, 1999). O objetivo desta pesquisa é o de investigar as representações maternas acerca do nascimento de um bebê com doenças orgânicas graves que pressupõem seqüelas.

\section{Método}

\section{Participantes}

No período de fevereiro a outubro de 2002 foram incluídas no estudo 11 mães de bebês com doenças orgânicas graves nascidos no Hospital São Paulo e no Hospital e Maternidade São Camilo. Foi considerada doença orgânica grave qualquer patologia que ocasionasse risco de seqüelas maiores. A composição da amostra deu-se na medida da ocorrência dos nascimentos consecutivos de bebês com tais alterações, nos dois centros de referência.

As informações sobre o bebê e a família foram obtidas do prontuário hospitalar e incluíram: nome do bebê e data de nascimento; nome, idade e escolaridade dos pais; número de gestações, duração da gestação e tipo de parto; diagnóstico do bebê. Consideramos serem esses dados suficientes para o propósito desta pesquisa, e procuramos assim evitar o excesso de informações preexistentes, objetivando a não contaminação e o não direcionamento das entrevistas. Com o objetivo de manter sigilo sobre as entrevistadas, os bebês foram identificados por iniciais.

O projeto foi aprovado pelo Comitê de Ética em Pesquisa da Universidade Federal de São Paulo (UNIFESP) e todas as mães assinaram o Termo de Consentimento Livre e Esclarecido para participação voluntária no estudo.

\section{Delineamento}

Foi realizado um estudo qualitativo (Buston, ParryJones, Livingston \& Wood, 1988; Demo, 2000; Minerbo, 2000; Patton, 1990) fundamentado no campo teórico-psicanalítico (Silva, 1993). O objetivo deste estudo implica um trabalho com fenômenos não-lineares e variáveis complexas. Demo (2000) esclarece que, no aspecto linear, apanhamos a extensão, ao passo que, no não-linear, revela-se a intensidade do fenômeno. Portanto, para fazermos isto, temos de trabalhar com pequenos grupos que jamais serão representativos da sociedade inteira mas que podem ser "exemplares".

(...) se estamos estudando um grupo de 10 pessoas em profundidade, torna-se esquisito aplicar percentagens, não porque não fosse possivel ao final das contas, mas porque transmite a idéia falsa de que as propriedades distribuem-se linearmente. Por exemplo, se quatro pessoas conectam felicidade com religião, não se poderia dizer que $40 \%$ das pessoas assim o fazem (p.156).

Tabela 1. Dados de identificação das entrevistadas

\begin{tabular}{ccccccc}
\hline No & $\begin{array}{c}\text { Identificação } \\
\text { do RN }\end{array}$ & \multicolumn{3}{c}{ Informações Maternas } & \multicolumn{2}{c}{ Informações do Recém-nascido } \\
\cline { 3 - 6 } & $\begin{array}{c}\text { Idade } \\
\text { (anos) }\end{array}$ & Escolaridade & Paridade & Classificação & Diagnóstico \\
\hline 1 & RA & 20 & Fundamental Completo & 1 & Termo & Mielomeningocele \\
3 & MS & 15 & Fundamental Incompleto & 1 & Pré-termo & Síndrome Genética a esclarecer \\
3 & B & 29 & Alfabetizada & 3 & Pré-termo & Meningocele \\
4 & D & 23 & Fundamental & 2 & Termo & Mielomeningocele \\
5 & G & 26 & Superior & 1 & Termo & Gastrosquise \\
6 & R & 40 & Analfabeta & 4 & Pré-termo & Cardiopatia congênita complexa \\
7 & J & 29 & Médio Completo & 1 & Pré-termo & Encefalopatia Hipóxico-isquêmica \\
8 & F & 21 & Médio Incompleto & 1 & Pré-termo & Malformação anorretal e genitália ambígua. \\
9 & R & 30 & Superior & 1 & Termo & Cardiopatia congênita (atresia pulmonar) \\
10 & R & 31 & Médio & 1 & Pré-termo & Malformação cerebral (paquigiria) \\
11 & G & 23 & Médio & 2 & Pré-termo & Perfuração e ressecção intestinal \\
\hline
\end{tabular}


Neste estudo, como não há uma amostra controlada de sujeitos com representatividade estatística, os depoimentos remetem à representatividade simbólica, possibilitando assim categorias de análise e a formulação de hipóteses abrangentes sobre o conteúdo do material pesquisado.

\section{Instrumentos}

O instrumento utilizado na obtenção dos dados constituiuse de uma entrevista semi-estruturada individual (Mannoni, 1993; Triviños, 1987). Tal opção está fundamentada no interesse de interferir o mínimo possível na formulação do discurso das entrevistadas, propiciando a livre associação de idéias, garantindo a continuidade do fluxo da entrevista e o acesso, a partir do roteiro comum de perguntas, ao conteúdo privilegiado pela pesquisa.

O tema indicado inicialmente foi: "Conte-me sobre seu filho." Essa proposta não-diretiva indagava a respeito da representação da mãe acerca desse bebê, representação aqui entendida como uma construção subjetiva.

Conforme refere Bleichmar (1983):

O termo representação possui um enraizamento que o torna perigoso. Se como representar se estivesse sustentando a tese de que o psiquismo copia o mundo real, voltando a “apresentá-lo" em forma de elementos mentais, ter-se-ia produzido o deslizamento ao empirismo. Quando empregamos o termo deve-se entender que não subscrevemos essa concepção, senão que consideramos a representação como uma construção (p. 17).

Os demais temas privilegiados no roteiro foram:

- A constituição da família.

- A inserção do bebê na constelação familiar.

- O transcurso da gravidez.

- O imaginário em torno da criança.

- Os projetos feitos para o bebê.

- Como foi o momento da comunicação do diagnóstico.

Estes pontos foram definidos a partir da experiência da pesquisadora, em UTIN, na observação, escuta e atendimento a mães de bebês que nasceram com doenças orgânicas graves.

Todas as entrevistas foram gravadas em fita cassete e transcritas integralmente.

\section{Procedimentos}

As mães foram informadas a respeito do trabalho de pesquisa em andamento antes do contato com a pesquisadora. Após o seu consentimento, a pesquisadora se apresentava, esclarecia os propósitos da pesquisa, indagava a respeito da disponibilidade da mãe para participar e então um horário era agendado. Este intervalo visou possibilitar à entrevistada pensar a respeito do seu desejo de participar do estudo. Todas as mães contatadas aceitaram o convite. No início da entrevista, a mãe era novamente esclarecida a respeito do objetivo da pesquisa em andamento, dos procedimentos, da gravação, bem como do conteúdo do termo de livre consentimento. As entrevistas tiveram duração de 35 minutos a uma hora.

\section{Análise de dados}

As entrevistas foram analisadas por meio do método qualitativo de análise de conteúdo de Bardin (1977) e foram organizadas em três etapas cronológicas. A pré-análise, a exploração do material e o tratamento dos resultados a partir de sua interpretação. Na primeira etapa travamos contato com o conteúdo das 11 entrevistas, contando com diversas leituras. Esta fase é chamada de "leitura flutuante", em analogia com a atitude do psicanalista (Bardin, 1977). Procedemos posteriormente ao recorte - a separação das partes do todo - dos textos em unidades comparáveis de categorização (Patton, 1990) e as agregamos - o agrupamento das partes separadas - em quatro categorias. Houve, portanto, uma redução do conteúdo das diversas entrevistas em unidades de sentido e a síntese dessas partes em categorias de análise. Realizamos então a análise propriamente dita. $\mathrm{O}$ acesso à gama de significados possíveis que se anunciaram a partir do conteúdo das entrevistas só pôde ser revelado pela análise interpretativa. Como sugere Herrmann (1979): "como na música, os sentidos possíveis do discurso têm uma existência apenas potencial, até que sejam interpretados" (p.26).

\section{Resultados}

\section{Análise e discussão das entrevistas}

Apresentaremos nesta seção as categorias emergentes: A fala inicial materna sobre o bebê; $O$ bebê do desejo e o bebê com alterações; À procura da causa; A repercussão da participação na entrevista. Iniciaremos cada uma das quatro categorias com trechos das falas das mães transcritos em itálico, para então procedermos à análise e discussão deste material. As idéias que não estiverem apresentadas com as referências de seus autores são compreensões sustentadas pelos autores deste artigo com base em suas referências teóricas.

\section{A fala inicial materna sobre o bebê}

A associação inicial ao tema da entrevista - "Conte-me sobre seu filho" - é reveladora de como a mãe está representando este bebê.

"Ah! (longo silêncio) Eu nem tenho muito a dizer, entendeu?..." (entrev. 4).

“Hum, o que você quer saber?” (entrev. 2).

“Ah! Ele? Conta assim o que está acontecendo?” (...) Bom, quando eu estava grávida eu não sabia que ele ia nascer com esse problema... Quando ele nasceu, ele não chorou até... O coração dele nasceu parado. Aí foi direto para UTI, né? E ele nasceu com má-formação, esse problema, que ele está até sendo internado aqui. Já passou por uma cirurgia. (...) nasceu junto à bexiga e o intestino (...) ele não tem ânus. Aí fizeram uma colostomia para sair o cocô. Sabe, até fazer a cirurgia que vai perfurar o ânus dele (...) e ele também tem um carocinho assim nas costas, bem aqui assim embaixo (...) Só isso que eu tenho pra falar dele..." (entrev. 8). 
"Contar da R., é (...) eu descobri que ela tinha um probleminha com 4 meses de gestação. (...) Coluna aberta, um cisto na cabeça e a hidrocefalia, é isso que ela tem. Que eu lembre é mais isso, é isso só (...) é só o que eu tenho pra falar” (entrev.1).

Várias das entrevistadas pareceram surpreendidas com o tema proposto. Nos trechos citados, observamos que a fala sobre os bebês se dá a partir do seu problema, podendo-se pressupor uma equivalência entre a doença do bebê e o bebê, como se o real desse corpo marcado impedisse qualquer possibilidade de simbolização a respeito dele (Jerusalinsky \& cols., 1999). As mães, portanto, não teriam mais nada a dizer para além do seu problema.

No nascimento ordinário de um bebê percebe-se que muitos projetos são sustentados. Inúmeras são as projeções quanto ao que ele poderá vir a ser, com quem se parece ou parecerá, do que virá a ter. O futuro está sendo proferido (Cramer, 1993). No nascimento de um bebê com patologias as projeções acerca de seu futuro podem ficar circunscritas a essa nomeação.

Para Arias (1999):

A gravidade da alteração (...) sofrida por uma criança pode ser variável, mas, em todos os casos, esta marca a afasta da normalidade (seja uma enfermidade já rotulada ou uma possível enfermidade ainda sem diagnóstico). Esta diferença a denomina: É um paralítico, é uma patologia genética (p. 294).

Outro aspecto a ser ressaltado nesta categoria diz respeito à busca materna por uma inscrição deste bebê:

“Ah! Eu queria saber como ele vai ficar, assim (...) queria ver alguma criança com um caso assim, eu não vi ainda, nem sei como é, não tenho nem idéia como que vai ser, aí eu queria saber como que ele vai ficar, se vai sofrer algum problema, assim... Por isso eu quero saber que tipo, só que eles não sabem explicar. Falou: - É esperar, falou para mim. Aí, eu queria saber se teve outro caso assim, queria ver, se alguma pessoa com esse caso aí, só que eu não vi ainda então eu não imagino como vai ser. (...) Só isso. Aí, você não sabe assim, um caso assim? Você não viu ainda igual a esse aí que tem o meu filho?" (entrev. 3).

A estranheza materna diante de seu bebê leva muitas vezes as mães à tentativa de inscrevê-lo em algum lugar de pertinência e reconhecimento a partir do seu diagnóstico, como se assim pudessem dizer a que família pertence esse bebê, com quem se parece, qual será o seu futuro. O reconhecimento que se daria pela linhagem familiar pode não se sustentar diante desse bebê diferente.

Observamos que a maior parte das entrevistadas iniciou seus discursos pelo momento da comunicação diagnóstica: foi quando essa criança passou a ser referida. Antes havia outro bebê que foi perdido pela irrupção do problema. Segundo Arias (1999):

\footnotetext{
"Mas quando a criança que chega para ocupar esse espaço: 'meu filho' não é normal, a criança é sentida como "um intruso”. Não é reconhecido como próprio. (...) A que família pertence este que é distinto?"'(p. 295).
}

\section{O bebê do desejo e o bebê com alterações}

Conforme discorremos na introdução deste trabalho, há um bebê sadio desejado em torno do qual se tece uma rede de projetos identificatórios. Esse bebê é motivo de prazer e regozijo. Nesta categoria abordaremos a perda desse bebê imaginado pelo nascimento do bebê com alterações e suas implicações na representação materna.

“Eu soube dos seis meses (...) Eu queria saber se ia ser menino
ou menina para comprar roupinha, aí que deu problema para
mim. Falou que tinha água na cabeça, que era urgente (...)
eu fiquei desesperada, porque eles falaram que o meu caso
era muito grave. Aí, eu tinha que ir fazer um outro ultra-som,
que eu pensei que podia ser que deu errado alguma coisa
(...) deu o mesmo problema de novo. Depois eu falei, eu vou
fazer de novo o ultra-som. Aí, veio de novo (...) eu vim e saiu
a mesma coisa de novo, que tinha água na cabecinha dele”
(entrev. 3).

(...) Aí quando no ultra-som de oito meses eu vim saber que era menina, mas aí depois que (...) que seria uma criança retardada, né (...) tudo isso eles me falaram. Aí pra mim, ela já ia vim com uma cabeça enorme mesmo, igual à que eles me falaram, sabe, ia vim, sei lá, uma criança... entendeu, porque... nossa! (...) foi bom até os oito meses (...) depois que eu fiquei sabendo é que veio as preocupações, tudo (...) eu não comia mais direito, sabe, eu queria só ficar saindo, se eu ficasse em casa era só chorando, pensando, entendeu, só queria ficar sempre saindo, saindo, conversando com as pessoas, nossa, foi horrivel (...) (entrev. 4).

“Tudo de bom (...) então foi uma gravidez planejada, ela foi esperada... Quando eu descobri que estava grávida foi o melhor presente (...) então assim até o sétimo mês, tudo o que eu tinha de bom para passar para ele dentro da minha barriga eu passei (...) mas assim... afetou muito a minha gravidez, então do sétimo mês para a frente eu quase não conversava com a minha barriga (...) eu entrei em desespero... Eu pensava que ele nasceria, faria a cirurgia e corresse um sério risco de não sobreviver, então era assim; eu não tinha mais planos, não tinha vontade de comprar nada para ele." (entrev.9).

“(...) eu imaginava assim (...) Ia nascer com saúde, por causa que eu sempre tive saúde e o meu marido também,(...) e nasceu diferente nada que a gente quer, né, então foi assim... de repente. (...) Eu assim no começo chorava muito, muito mesmo, eu já estava entrando em depressão porque eu só sabia chorar, não fazia nada na minha casa, nada, nada, nada... Só ficava deitada chorando... Sem comer até..." (entrev.8).

Esses relatos indicam um hiato entre o bebê esperado/ sonhado e este outro - que chega sem ter lugar esperado, no lugar de quem era aguardado -, agora a criança do diagnóstico, marcada no seu corpo. Com freqüência as mães dizem de seu filho "estas crianças" (Arias, 1999), como podemos observar no depoimento da entrevistada $n^{\circ}$ 4. Esse que se anuncia tão doente, frágil, decepcionante 
para sua mãe, parece não sustentar um lugar de bebê, visto que eles geralmente são imaginados como bonitos e saudáveis. É inegável o comprometimento desse momento de extremo investimento no bebê.

Como sugere Bleichmar (1983):

Quando se diz então que o narcisismo da criança é o narcisismo dos pais, não se quer apenas dizer com esta afirmação que os pais satisfazem sua própria necessidade de estima hipervalorizando o filho, que é seu produto, senão também que a vivência do narcisismo satisfeito da criança tem sua origem nos pais (p. 38).

A partir da notícia do diagnóstico, as mães se deparam com a perda/luto do bebê desejado. Esta perda mobiliza intensos afetos e idéias depressivas. No artigo Luto e Melancolia, Freud (1917/1976) definiu o luto como “(...) de modo geral, é a reação à perda de um ente querido, à perda de alguma abstração que ocupou o lugar de um ente querido, como o país, a liberdade ou o ideal de alguém." (p. 275). Descreveu ainda, entre os seus traços, um desânimo profundamente penoso, a cessação de interesse pelo mundo externo e destacou como distintivo da melancolia a perturbação da auto-estima. Nesse artigo Freud introduziu a expressão "trabalho de luto", cuja noção se aproxima da noção mais geral de elaboração psíquica, concebida como uma necessidade para o aparelho psíquico de ligar as impressões traumatizantes (Laplanche \& Pontalis, 1983).

Além da perda do bebê desejado, as mães confrontam-se com o decréscimo na sua auto-estima. $\mathrm{Na}$ introdução deste artigo, aludimos ao sentimento de regozijo materno - sua majestade, a mãe - frente ao nascimento do bebê normal desejado. A mãe sente-se orgulhosa pelo "seu feito", a seus olhos ele a significa como boa por ter "produzido" esse bebê. A mãe do bebê com alterações, freqüentemente, se sente incompleta, incapaz. Pode-se inferir que, se o bebê ficou marcado por aquilo que não tem, pelo que não é, a mãe poderá sentir-se igualmente marcada como deficiente nessa posição.

Outro aspecto a ser destacado nesta categoria diz respeito às perdas das referências maternas.

"Não sei, acho que no começo vai ser meio difícil, tem que ter um cuidado assim, só para ela, né? (...) só fico imaginando como cuidar dela... vou ter que ser uma enfermeira, né? (...)” (entrev. 11).

“Eu, pra mim, eu sei lá, eu imagino assim, que ela vai pra casa, eu sei que vou ter sempre que tá no médico com ela, entendeu, mas aí eu imagino ela como minha filha, entendeu? O mesmo carinho que eu der pra minha filha, pra ela vou dar o dobro, mais ainda também... Acho que a minha vida... vai ser bastante corrida também, né, assim porque vai ser dividido o meu amor entre as duas, e a D. e mais ainda... eu sei que vou ter que tá sempre correndo com ela assim, também com acompanhamento de médico, essas coisas, né?...” (entrev. 4).

O saber que perpassa tantas gerações e remete a mãe aos cuidados que lhe foram reservados e transmitidos por sua própria mãe fica, freqüentemente, comprometido diante desse outro bebê. Ao se sentir destituída do lugar de maternagem de seu bebê sadio imaginado ela pode assumir, ante o bebê com problemas, um lugar de cuidadora do corpo (Jerusalinsky, 1999).

O último aspecto a ser ressaltado nesta categoria refere-se à comunicação do problema durante a gestação:

\begin{abstract}
“(...) Olha, horrível, não via a hora de ganhar para ver, foi assim, contei nos dedos os dias, foi uma angústia muito grande... Ah, que eu vi ela assim, eu falei meu Deus, minha filha é assim (...) uma criança gordinha. Porque pra mim já ia nascer com a cabeça enorme (...) Pra mim ela seria igual àquelas crianças de sei lá, que não, aquelas crianças, não sei nem falar o nome daquelas crianças, né? Uma criança parada, né, pra mim seria uma criança assim, não tivesse movimento de nada, pra mim ela seria uma criança assim, entendeu, com problema de não falar..." (entrev.4).
\end{abstract}

“(...) Ah, eu imaginei que ele ia sair diferente, não pensei que ele ia ficar assim bonzinho, que ele ia, o olhinho dele está direitinho, a boquinha, o narizinho, eu pensei que ia ser pior, assim. Eu pensei mesmo assim. Eu pensei que a cabecinha dele ia ser bem grande. Não era a cabecinha dele que era grande, tinha uma bolsinha atrás, era isso aí que era muito grande (...)" (entrev. 3).

“(...) foi triste, mas agora eu já estou bem melhor... Já quando se está grávida se espera outra coisa (...) mas agora, depois que ela nasceu, eu já vi que era outra diferente, né? (...) esperava que ela estivesse pior do que ela está... Com mais problemas, com mais deformações no corpo. Ela está bem melhor do que eu imaginava, é isso... Antes foi difícil, chorava bastante (...) Eu imaginava ela pior (...) com mais deformidade no corpo (...) mais perna torta. A gente sempre quer saber se tem todos os dedinhos, se tem unha, cabelinho, é isso. Eu vi ela do jeito que eu queria, com tudo o que ela tinha, tudo o que todo mundo tem, né..." (entrev.1).

Quando uma mulher está grávida fantasia a aparência de seu filho, havendo um lugar de pertinência familiar nesse parecer-se antecipado. Nos trechos citados, as mães relatam o horror por não poder dar representação a seu bebê em função da perda do reconhecimento pela similaridade. No entanto, as projeções feitas modificam-se a partir do momento em que as mães vêem seus filhos, demonstrando alívio no encontro com um bebê reconhecido como portador de traços iguais aos dos pais. Tem nariz, cabelinho, pezinhos e dedinhos.

No transcorrer da maior parte dos relatos foi possível acompanhar como o bebê, que inicialmente aparecia nas entrevistas igualado a uma doença, foi ganhando nomeações outras. Na nomeação há a possibilidade de um lugar de existência: anuncia-se um olhar para o bebê, indicando uma rede de representações possíveis, mesmo que incipientes. Garcia-Roza (1986) refere que, frente ao indeterminado, surge o mito capaz de narrar a ordem primeira, concebida não como anterior ao caos, mas como efeito dele. O que não está inscrito tem que ser representado psiquicamente.

As mães deparam-se com quadros diagnósticos graves e pode-se compreender a recorrente dificuldade delas para a escuta do diagnóstico em questão, daí uma dupla implicação: 
se por um lado é necessário que os pais não se resignem ao problema, garantindo as possibilidades de investimentos, por outro lado, e paradoxalmente, é necessário que se resignem aos limites impostos por ele (Silva, 2000).

\section{À procura da causa}

Esta categoria é concernente a como as mães entendem a alteração do bebê bem como às causas atribuídas a ela. Dessa forma, temos como propósito acompanhar como as mães vão tentando dar sentido a esses nascimentos, de que maneira o fazem, além de discutir suas implicações.

“(...) eu penso se Deus mandou assim para mim, eu cuido dele, como vier, né?... Eu aqui planejava ter esse filho, não é que eu não planejava nem nada. Eu queria saber também por que saiu assim... Eu perguntei para o médico... Eu pensei que é, eu tomei muito é, eu tomei oito anos comprimido. (...) Ele falou que não era por isso, não. Que ia, que ia nascer, ia acontecer mesmo... Aí, perguntou para mim se eu e o meu marido éramos parentes, mas também não é. Perguntou se eu tinha algum parente com problema assim; não tenho, nem meu marido tem nenhum parente assim parecido, assim com esse problema aí, só isso... Eu pensei assim, lá (país de origem) nem no hospital eu fui quando estava grávida deles. Só para nascer mesmo que eu ia para o hospital e não deu nenhum problema. Agora que eu estou seguindo o tratamento direitinho, deu esse problema para o meu filho..." (entrev. 3).

“(...) Às vezes, eu falo assim: - Nossa, meu Deus! Por que que eu tenho que passar por tudo isso? Se alguém tem que sofrer, que seja eu e não ele... Ah, porque às vezes eu fico pensando (...) a outra gravidez que eu perdi de repente, não era para eu ficar grávida de novo, e eu insisti...” (entrev. 10).

“Ah! Não sei, olha, muitas vezes eu falei; meu Deus do céu, por que comigo, eu falei; não sei se tenho forças para criar uma criança assim, entendeu? (...) Será que eu fiz alguma coisa assim para merecer isso, né (...) Ah! Sei lá, assim, as vezes as pessoas falam que eu sou muito egoísta (...) será que Deus está me mandando uma criança assim para mim ser mais humilde com as pessoas?” (entrev. 4).

"Vinha na minha cabeça que eu era uma pessoa incapaz de ter, que talvez Deus esteja me castigando por alguma coisa... não me vinha nada, mas vinha só que era um castigo, tudo que os médicos falavam, olha a J. pode ter isso, eu falava, ah, é minha culpa. A J. pode não enxergar, aquilo para mim foi a morte. Eu cheguei até a falar que eu furaria meus olhos se isso acontecesse com ela. (...) eu que a J. veio com uma missão muito importante (...) até de unir a família (...)” (entrev. 7).

"Eu entrei em desespero (...) deu a revolta com Deus, com tudo... Porque tanta gente abandona os filhos... gente que tira e eu que esperava tanto, planejei tanto, de repente Deus estava me tirando ele (...) então eu comecei a tentar descobrir aonde eu tinha errado, quais eram os meus pecados, porque eu deveria estar pagando algum pecado muito sério, alguma coisa (...) uma punição... uma punição, e me bateu aquela revolta (...)
Aí eu falei, ou é para, sei lá, tentar unir mais as famílias (...)” (entrev. 9).

No trecho da entrevista 3 observamos que, na busca por um saber que possa dar ordem às causas do nascimento desse bebê com problemas, a mãe recorre à palavra do médico, a um saber "científico". Todavia tal saber não oferece uma resposta a sua questão. Busca então por uma ordem explicativa religiosa, na qual parece projetar um saber possível. Depois reafirma seu desejo pelo bebê, subentendendo que, se o bebê foi desejado, então deveria nascer bem, mas essa premissa da ordem do psicológico, sustentada na onipotência do desejo, também fracassa.

$\mathrm{Na}$ busca de ordenamento situa-se a possibilidade de rehistorização desse filho e da própria subjetividade da mãe, como um mapeamento em que o afeto vai podendo ser ligado (trabalho de elaboração psíquica).

As explicações via religiosidade podem indicar uma (re)tomada de sentido, mas também implicar uma crença onipotente, na qual a onipotência procurada na ciência não se sustenta. Um tema recorrente é a atribuição de uma função heróica a esse bebê, como uma forma de significar o porquê de seu nascimento com problemas. Ao mesmo tempo em que se observam as tentativas da mãe de dar representação ao traumático, de rearticulação egóica, é necessário que se possa considerar o risco implicado para o bebê de ficar perpetuado num mito religioso rígido, seja na sua função heróica ou na martirizante (Jerusalinsky ,1999).

A formação de projetos identificatórios rígidos pode indicar riscos psíquicos tanto para o bebê como para a mãe. Jerusalinsky (1999) considera que:

No real, esta criança não é como os outros, e esta irrupção do limite num lugar em que não se espera produz (...) um efeito sinistro (...) os pais podem fazer esforços explicativos para suavizar este efeito (...) Tornar-se-ão, então, alternativamente mártires ou vítimas de um castigo (...) missionários reparatórios, talvez estóicos e orgulhosamente guerreiros sociais por seus filhos (p. 102).

\section{A repercussão da participação na entrevista}

Nesta categoria, abordaremos a repercussão que a participação nas entrevistas teve na representação materna acerca do bebê.

“(...) gostei... pensei, de repente, se vão fazer um folheto para mães que estão passando por problemas, eu não conheço alguém que ta passando pelo mesmo problema, será que eu sou a única? (...) vocêfez perguntas que ninguém fez...” (entrev. 10).

“(...) eu não tive auxílio nenhum assim, eu como mãe, a gente só falava da neném, da neném, né? E então eu achei até um trabalho legal porque ninguém instruiu assim; você pode passar por isso, isso, isso, (...) então você vai cair de novo... Então eu achei assim um trabalho legal, porque pode ajudar outras mães que possa passar pelo que eu passei... Então, às vezes, nem com a minha mãe. A gente conversa, mas não é como eu posso falar, não é tudo... Só de falar, já é muito bom... hoje eu falo que a parte do corpo que mais dói em uma mãe é o filho... Só de falar, já é muito bom...” (entrev. 5). 
“(...) Porque eu estava precisando desabafar um pouquinho. Depois eu fico chorando sozinha, assim é muito ruim. Igual um dia antes mesmo de eu vir para cá, que eu não sei o que eu falei, que o meu marido... eu sei que eu falei do meu leite e ele falou, nem para dar leite você não serve, aí fiquei me sentindo meio inválida...” (entrev. 11).

“(...) eu senti falta assim, de um apoio... Eu aceitei porque eu achei bacana, porque eu acho que eu senti isso, eu senti essa falta... me senti bem desabafando, colocando uma história para alguém que eu não conheço, que eu nunca vi, mas que eu sei que está conseguindo compreender, absorvendo e até entender um pouquinho do que eu estou sentindo... porque para as pessoas que eu contei a história são amigos e tal e é muito fora da realidade deles... Então colocar assim pra alguém que talvez entenda também, está fazendo um trabalho a respeito disso e tudo o mais, é interessante... eu falei: por que não expor a história, né?...” (entrev. 7).

Cramer (1993) considera que "No encontro com um profissional que não julga, que está investido do poder da ciência e que sabe escutar, há um efeito revelador espantoso: o efeito do encontro" (p. 21).

A partir desses relatos observamos que, para a maioria das entrevistadas, falar a respeito do bebê para além do seu problema - o que no início da entrevista causou estranhamento - pareceu propiciar alívio. As entrevistadas mostraram-se receptivas à possibilidade de serem ouvidas por alguém de fora de suas relações habituais, sem críticas e com pouco direcionamento. A maior parte delas transformou em demanda própria o falar acerca desse nascimento, de modo que os temas do roteiro de entrevistas apareciam de forma espontânea. Decorre disso o nosso reconhecimento da necessidade de uma "escuta" analítica no hospital, no período da internação do bebê.

Outro aspecto a ser destacado nessa categoria diz respeito ao anúncio materno de um lugar de similaridade familiar para esse bebê.

“(...) ela é bonitinha... eu imaginava até que ela tinha problema na cabeça (...) eu acho que ela parece com ele (referindo-se ao pai da R.), e ele gosta, né? Ele já queria ter uma filha mulher... fiz a vontade dele" (entrev. 4).

"Ah, eu queria, eu estava curiosa para saber como ia ser (risos). Achei bom, você estar perguntando essas coisas, achei bom. No começo eu fiquei curiosa... É que eu fiquei muito preocupada quando eu soube, quando ele tinha esse problema aí. (...) Se ele fosse nascer normal, i nascer hoje ou amanhã que era dia 2/5 (...) sempre os meus filhos nascem antes do mês que marca (...)" (entrev. 3).

Nesse trecho (entrev. $n^{\mathbf{o}}$ 3) a mãe anuncia um lugar de similaridade com os seus demais filhos. "Todos nascem antes do tempo”. No início de sua entrevista, a mãe indagava quanto a um lugar de reconhecimento para um caso assim, a partir do saber de outros casos com o mesmo diagnóstico. Saber que, supunha, os médicos deveriam ter.

Dolto (1983) sustenta :
(...) a maioria das pessoas (...) acredita ainda que o psicanalista vai fazer isto ou aquilo, vai influenciar, vai moralizar, vai estimular, aconselhar, em suma, agir com suas palavras como um medicamento por uma espécie de sugestão... O que marca a especificidade do psicanalista é a sua escuta, que permite entender em vários níveis o sentido emocional subjacente ao discurso manifesto... (p. 10).

Apesar de não ter havido no processo das entrevistas qualquer intenção terapêutica, foram observados efeitos terapêuticos. O pouco direcionamento dado no processo da entrevista parece ter sido tomado pelas mães como um estímulo a sua fala, propiciando a possibilidade de atribuir significados a sua vivência, na presença de alguém que demanda palavras e que está em possibilidade de escuta. Em síntese, uma experiência organizadora para a mãe (Cramer, 1993; Dolto, 1983; Jerusalinsky,1999).

Segundo Druon (1999), referindo-se ao trabalho que desenvolve no Centro de Medicina Neonatal de Port-Royal (Paris),

Postulamos a hipótese de que evocar os elementos traumáticos na sua emergência diminuirá seus impactos no só-depois (après-coup). Ajudar os pais a falar desse "nascimento diferente dos outros" é partir da idéia de que o não dito favorece a formação de um quisto que destila em seguida, dia após dia, o veneno que envenena a relação da criança com os pais (...) (p. 41).

\section{Considerações Finais}

Emerge como reflexão, a partir da análise das entrevistas, a necessidade de uma escuta analítica precoce dessa mãe, no período da internação do bebê na UTIN. Há um trauma que precisa de palavras para ser enunciado; a palavra significada rearticula, deslizando do traumático do não-representável (Bleichmar, 2000).

Muitas são as ações urgentes no início da vida de um bebê de risco orgânico. O diagnóstico, ao ser igualado pelas mães a um destino traçado precocemente, do mesmo modo que a negação dos limites impostos por ele, pode indicar riscos psíquicos na constituição desse vínculo mãe-bebê (Druon, 1999; Jerusalinsky, 1999; Silva, 2000). Muitas vezes nós, profissionais envolvidos no atendimento ao bebê e de seu entorno, somos testemunhas desses indicadores, deparando-nos assim com um bebê de risco e em risco, o que faz necessário que se pense tanto na reanimação orgânica quanto nas questões psíquicas aí implicadas.

Ao considerar que o comprometimento do bebê é da ordem do orgânico e tem um determinado limite intransponível, faz-se importante pensar nas possibilidades simbólicas que podem se anunciar e que comportam muitas significações diferentes.

Silva (2000) sugere distinções entre o que é um sintoma psíquico e o que são as dificuldades advindas do distúrbio orgânico; o que é resultado de um limite imposto pela lesão e o que veio se somar a ela. Isto é, procura-se distinguir o que é necessário e o que é contingente. Os sentimentos e atitudes dos pais têm grande influência no tratamento de seus filhos. Casos com quadros diagnósticos semelhantes podem ter 
desenvolvimentos diferentes, pelas inscrições subjetivas que incidem sobre eles. Cada uma das entrevistadas representou o nascimento desse bebê a partir de sua própria singularidade histórica. Mas as questões fundamentais, estruturantes da experiência suscitada pelo anúncio da doença do bebê, foram similares.

A partir do reposicionamento subjetivo da mãe e também do nosso posicionamento como profissionais envolvidos no atendimento ao bebê e seu entorno, enquanto estão sob os nossos cuidados na UTIN, a história desse vínculo mãe-bebê, que está se constituindo, pode ter diferentes desdobramentos. Quanto antes se faça intervenção, melhor será para todos os envolvidos. A intervenção psicanalítica precoce aponta para uma proposta de prevenção da psicopatologia da constituição do vínculo mãe-bebê (Battikha, 2001).

\section{Referências}

Arias, M. I. (1999). A Escuta do Indizível. Em A. Jerusalinsky, C. Tkach, C. Sykuler, E. Tadey, E. Coriat, E. Levin, E. Levy, J. Garbarz, L. Ranieri, L. Coriat, M. Groisman, M. Arias, O. H. Foster, P. C. Brandão, R. Sued, S. Bruckman, S. Molina \& S. C. Paez (Orgs.), Psicanálise e Desenvolvimento Infantil (pp. 294-298). Porto Alegre: Artes e ofícios.

Bardin, L. (1977). Análise de Conteúdo. Lisboa: Edições 70.

Battikha, E. C. (2001). Intervenção precoce no vínculo mãe-bebê em uma unidade de terapia intensiva neonatal. Em M. C. Camarotti (Org.), Atendimento ao bebê: Uma abordagem interdisciplinar (pp.43-48). São Paulo: Casa do Psicólogo.

Bleichmar, H. (1983). Depressão: Um Estudo Psicanalítico. Porto Alegre: Artes Médicas.

Bleichmar, S. (2000). Clínica psicoanalítica y neogenéseis. Buenos Aires: Amorrortu/editores.

Buston, K, Parry-Jones, W., Livingston, A. B. \& Wood, S. (1988). Qualitative research. British Journal of Psychiatry, 9, 172197.

Cramer, B. (1993). Profissão Bebê. São Paulo: Martins Fontes.

Demo, P. (2000). Metodologia do Conhecimento Científico. São Paulo: Atlas.

Dolto, F. (1983). Prefácio. Em M. A. Mannoni (Org.), A Primeira Entrevista em Psicanálise (pp.9-29). Rio de Janeiro: Campus

Druon, C. (1999). Ajuda ao bebê e aos seus pais em terapia intensiva neonatal. Em D.B. Wanderley (Org.), Agora eu era o rei (pp.3554). Salvador: Ágalma.

Freud, S. (1976). Sobre o Narcisismo: Uma Introdução. Em Edição Standard Brasileira das Obras Psicológicas Completas de Sigmund Freud. Rio de Janeiro: Imago Editora. (Trabalho original publicado em 1914)
Freud, S. (1976). Luto e Melancolia. Em Edição Standard Brasileira das Obras Psicológicas Completas de Sigmund Freud. Rio de Janeiro: Imago Editora (Trabalho original publicado em 1917)

Garcia-Roza, L. A. (1986). Acaso e repetição em Psicanálise: uma introdução à teoria das pulsões. Rio de Janeiro: Jorge Zahar.

Herrmann, F.A. (1979). Andaimes do Real I: Uma revisão crítica do método da psicanálise. São Paulo: EPU.

Jerusalinsky, A. (1999). A direção da cura do que não se cura. Em A. Jerusalinsky, C. Tkach, C. Sykuler, E. Tadey, E. Coriat, E. Levin, E. Levy, J. Garbarz, L. Ranieri, L. Coriat, M. Groisman, M. Arias, O. H. Foster, P. C. Brandão, R. Sued, S. Bruckman, S. Molina \& S. C. Paez (Orgs.), Psicanálise e desenvolvimento infantil: um enfoque transdisciplinar (pp. 89-106). Porto Alegre: Artes e Ofícios Editora.

Jerusalinsky A., Tkach C., Sykuler C., Tadey E., Coriat E., Levin E., Levy E., Garbarz J., Ranieri L., Coriat L., Groisman M., Arias M., Foster O. H., Brandão P. C., Sued R., Bruckman S., Molina, S. \& Paez, S. C. (Orgs.) (1999). Psicanálise e desenvolvimento infantil: um enfoque transdisciplinar. Porto Alegre: Artes e Ofícios Editora.

Laplanche, J. \& Pontalis, J.B. (1983) Vocabulário da Psicanálise. São Paulo: Martins Fontes

Mannoni, M. A. (1983). A Primeira Entrevista em Psicanálise. Rio de Janeiro: Campus.

Mathelin, C. (1999). Da pulsão de morte ao desejo de vida, ou as vicissitudes de uma terapia intensiva Em D. B. Wanderley (Org.), Agora eu era o rei. (pp. 61-79). Salvador: Ágalma.

Minerbo, M. (2000). Estratégias de Investigação em Psicanálise. São Paulo: Casa do Psicólogo.

Patton, M. Q. (1990). Qualitative evaluation and research methods. Newbury Park: Sage Publications.

Silva, A. P. P. (2000). A criança com Distúrbios Neurológicos e a Psicanálise. Dissertação de mestrado, Universidade de São Paulo, São Paulo.

Silva, M. E. L. (Org.) (1993). Investigação e Psicanálise. Campinas: Papirus.

Triviños, A. N. S.(1987). Introdução à Pesquisa em Ciências Sociais. São Paulo: Atlas.

Wanderley, D. B. (Org.) (1999). Palavras em torno do berço. Salvador: Ágama.

Winnicott, D. B. (Org.) (1993). Textos Selecionados: da pediatria à Psicanálise. Rio de Janeiro: Livraria Francisco Alves Editora. (Trabalho original publicado em 1956)

Recebido em 07.07.2005

Primeira decisão editorial em 31.10.2005

Versão final em 13.06.2006

Aceito em 13.12.2006 